\title{
Pemanfaatan Layanan Informasi Guna Mencegah Terjadinya Dampak Negatif Perilaku Pacaran di Kalangan Remaja
}

\author{
Vivi Yuliani ${ }^{1 *}$, Yeni Karneli ${ }^{2}$ \\ Universitas Negeri Padang ${ }^{12}$ \\ *) Correspondence Author, e-mail: viviyuliani22@gmail.com
}

\begin{abstract}
Abstrak: Keterlarikan antar lawan jenis pada masa remaja sudah dipastikan sangat wajar. Pada masa remaja memang merupakan masa transisi, dimana seorang individu pada masa perkembangan dari anak-anak menuju dewasa. Ketertarikan dengan lawan jenis, rasa ingin memiliki, itu akan mewujudkan suatu hubunga yang saat ibi sedang marak-marakanya yaitu pacaran. Hubungan pacaran itu dianggap penting bagi remaja. pada masa dulu pacaran itu sangat berhati-hati untuk sekedar pegangan tangan saja itu hal yang tabu, namun pada masa kini pacaran dapat menimbulkan hal negatif, seperti seks pranikah. Perilaku negatif ini terjadi dikarenakan kurangnya informasi yang didapat oleh remaja. tujuan penelitin ini agar dapat mengetahui penggunaan layanan informasi guna mencegah dampak negtif dari pacaran di kalangan remaja. Dengan melihat dari beberapa artikel yang terkait didapat hasil bahwa faktor utama dampak negatif ini timbul karna media informasi, dan kurangnya pemberian layanan informasi yang memadai terkait pendidikan kesehatan reproduksi. Layanan informasi ini sangat berguna agar rasa ingin tau remaja terkait seks itu tidak disalurkan dengan cara berpacaran, melainkan dengan cara remaja mendapat pengetahuan yang lengkap terkait kesehatan reproduksi sehingga tidak penasaran dan mencoba-coba dengan pacaran.
\end{abstract}

Kata kunci: Layanan informasi, dampak negatif perilaku pacaran, remaja.

Article History: Received on 08/03/2020; Revised on 06/06/2020; Accepted on 12/06/2020; Published Online: 11/7/2020.

\begin{tabular}{l} 
(c) (1) \\
\hline PENDAHS is an open access article distributed under the Creative Commons Attribution License, which permits unrestricted use, \\
distribution, and reproduction in any medium, provided the original work is properly cited. (02020 by author.
\end{tabular}
merupakan masa transisi antara anak-anak menuju kedewasaan. Pada masa remaja tentunya banyak sekali perubahan pada diri individu, apabila terjadi kesalahan dalam pemberian informasi terhadap remaja maka akan berdampak pada perubahan perilaku individu selanjutnya.

Masa Remaja terdapat beberapa perubahan, seperti perubahan fisik maupun psikologis (Evi, Sudirman, \& Suriah, 2013). Perkembangan secara fisik ditandai dengan semakin matangnya organ-organ tubuh, termasuk organ reproduksi. Perkembangan pada kematangan pribadi dan kemandirian merupakan perkembangan psikologis yang sudah mulai matang. Ciri khas dari perkembangan psikologis yang sudah mulai matang biasanya ditandai dengan timbul rasa tertarik terhadap lawan jenis, misalnya lebih suka bergaul dengan lawan jenisnya, lebih suka curhat terhadap lawan jenisnya, 
kemudian ada pula yang sudah mencapai kepada perilaku yang sudah umum seperti saat ini yaitu berpacaran.

Pacaran merupakan perasaan suka terhadap lawan jenis, yang kemudian berlanjut kepada terjalinnya ikatan yang lebih dari sekedar teman. Selain itu menurut Himawan, 2007 dalam (Maimunah, 2016) pacaran meruapan proses penjajakan antar individu untuk saling menjaling cinta kasih. Hubungan pacaran yang dilakukan oleh remaja itu dianggap penting olehnya. Menurut (Meilani \& Setiyawati, 2017) pacaran meruapan hubungan intim atau dekat dengan lawan jenis. Terdapat tiga pandangan tentang pacaran 1) pacaran merupakan cinta yang menggebu-gebu terhadap lawan jenis; 2) pacaran identik dengan kegiatan seks, hingga akhirnya pacaran akan melakukan hubungan seks atas dasar suka sama suka; 3) pacaran merupakan suatu ikatan perjanjian untuk saling mencintai, saling percaya, saling setia sampai ke jenjang yang lebih tinggi yaitu menikah. Secara umum pacaran ini bermanfaat untuk menikmati kebersamaan dengan orang lain (Santrock, 2003). Bagi seorang remaja itu dengan berpacaran akan merasakan dicintai, kasih sayang, penerimaan lawan jenis, rasa aman dari seseorang pacar. Berpacaran dapat melatih remaja untuk terbuka, melatih umpan balik, dan menyelesaikan konflik. Kemudian menurut Hurlock, 1980 dalam (Maimunah, 2016) menyatakan bahwa berpacaran itu dapat meningkatkan keterampilan remaja dalam bersosial yang baik, baik hati, dan menyenangkan.

Pada zaman sekarang pacaran yang terjadi tidak semuanya sama dengan apa yang diutarakan oleh Hurlock namun saat ini yang terlihat di lapangan remaja yang berpacaran malah menimbulkan dampak negatif, dahulu berpegangan tangan adalah hal yang tabu, namaun pada remaja masa kini berpacaran itu lebih vulgar dari beberapa tahun yang lalu berdasarkan penelitian yang di lakukan KPAI di 12 kota dalam (Maimunah, 2016). Pada masa kini berpacaran dapat menimbulkan dampak negatif seperti seks pranikah di kalangan remaja. Seks pranikah adalah hubungan seks yang di lakukan sebelum adanya hubungan pernikahan. Sejalan dengan pendapat Djamba. 2013 dalam (Rahardjo, 2017) bahwa seks pranikah merupakan aktivitas seksual yang di lakukan individu dengan individu lain sebelum menikah. Perilaku seks pranikah ini biasanya dilakukan oleh remaja yang didasari oleh rasa sayang dan cinta yang berlebihan. Prilaku negatif dari pacaran ini terjadi karena kekurangan informasi tentang sistem reproduksi dan tingkat pengetahuan tentang kesehatan reproduksi remaja dan sikap remaja tentang pacaran dengan perilaku pacaran pada remaja. Sejalan dengan itu prilaku pacaran dipengaruhi oleh faktor internal salah satunya faktor hormon, kurangnya informasi mengenai seks dan jenis kelamin (Meilani \& Setiyawati, 2017).

Kurangnya informasi mengenai sistem reproduksi (seks) menyebabkan timbulnya perilaku pacaran yang negatif. Maka peneliti merasa perlunya pemanfaatan layanan informasi kepada remaja guna mencegah dampak negatif dari pacaran. Karena layanan informasi dapat memberikan pemahaman terhadap sesuatu yang dirasa perlu untuk menumbuhkembangkan individu sesuai dengan tahap perkembangannya.

\section{METODE}

Metode penelitian ini menggunakan penelitian deskriptif komperatif degan literatur untuk mencari tau pemanfaatan layanan informasi untuk mencegah dampak negatif dari pacaran. 


\section{Pembahasan}

\section{Faktor Penyebab Dampak Negatif Pacaran}

Perilaku pacaran di lihat dari berbagai pengertian para peneliti terdahulu identik dengan terjadinya seks pranikah. Menurut (Meilani \& Setiyawati, 2017) pacaran akan meningkatkan resiko terjadinya hubungan seksual pranikah karena di dalam perilaku pacaran diketahui terjadinya aktivitas dengan lawan jenis baik itu kontak fisik mau pun tidak kontak fisik. Faktor yang mempengaruhi terjadinya dampak negatif pacaran ini tentunya ada faktor internal dan external. Sejalan dengan itu faktor yang mempengaruhi perilaku menyimpang dari pacaran menurut (Evi et al., 2013) yaitu faktor intrinsk yaitu pengetahuan, motivasi, dan tindakan. Pengetahuan tentang perilaku pacaran sangat penting karena pada masa sekarang lebih banyak yang memicu, karena kurangnya pemahaman informasi seprti ngobrol dan berkomunikasi menggunakan handphone sewajarnya menjadi berkomunikasi yang mengarah ke hubungan sksual. Motivasi yang diperoleh dari informen sangat mempengaruhi. Kemudian faktor eksternal yaitu peran kelurga, peran teman sebaya, dan sumber informasi.

Menurut (Hastuti, 2017) perilaku seksual remaja didorong oleh matangnya hormon seksual dan organ-orga reproduksi sehingga masa remaja cenderung memiliki tingkat seksual yang tinggi. menurut beberapa penelitian dalam (Hastuti, 2017) pornografi juga dapat meningkatkan perilaku seksual pada remaja, karena pornografi adalah tulisan, gambar, televisi, gadget, koran, atau bentuk komunikasi lain yang dapat melukiskan orang yang hampir sebagian besar perempuan namun tak sedikit kemungkinan laki-laki juga anak-anak dalam pose yang erotis (menggairahkan secara seksual), aktivitas seksual yang menantang, dan menyimpang dari apa yang di sebut sehat dan normal. Kemudian (Hastuti,2017) mengatakan bahwa konsultasi seks yang diberikan melalui media elektronik seperti penayangan filem atau gambar saat dilakukannya pendidikan seks disalahgunakan atau terjadi salah presepsi yang menyebabkan pemahaman yang kurang tepat terhadap kesehatan reproduksi, ini merupakan faktor terjadinya tindakan menyimpang saat pacaran.

Menurut (Evi et al., 2013) faktor teman sebaya juga mempengaruhi perilaku menyimpang dari pacaran, terkadang teman mengajak untuk melakukan hal yang sama, pengaruh dari media masa, dan pengaruh dari sumber informasi.

\section{Upaya Pecegahan Terjadinya Dampak Negatif dari Pacaran}

Berdasarkan uraian diatas maka upaya pencegahan terjadinya dampak negatif dari pacaran menggunakan layanan informasi menurut (Evi et al., 2013) yaitu dari beberapa segi sebagai berikut: 1) Pemberian pengetahuan melalui layanan informasi: Memberikan pengetahuan mengenai pacaran sehat terhadap remaja tersebut. Kemudian berdasarkan informasi bahwa untuk menghindari perilaku pacaran yang tidak sehat bisa dengan cara menjaga jarak dengan pasangan, berusaha mengendalikan diri dengan bisa menolak perbuatan yang dapat menimbulkan atau mengarah ke perilaku negatif. Selanjutnya dengan cara mendapat info terkait pendidikan kesehatan reroduksi dan bekerjasama dengan BKKBN; 2) Motivasi diri; 3) Tindakan: Tindakan yang dapat dilakukan yaitu memegang prinsip untuk jauh dari hal/perilaku negatif, harus menjaga diri, menolak 
pasangan jika mengajak untuk berhubungan seksual, menjauh dari teman yang pacaran sudah terlewat batas, dan selalu berfikir positif; 4) Keluarga: Membangun komunikasi antara orang tua dan anak (remaja) sehingga remaja mendapat informasi yang benar, selain pengawasan dari orang tua, tentunya informasi dari orang tua terkait hubungan antara lawan jenis juga dapat mengurangi terjadinya dampak negatif dari pacaran di kalangan remaja; 5) Guru BK Memberikan kegiatan ekstra kurikuler yang padat terhadap remaja agar remaja tersebut disibukan dengan kegiatan sekolahnya yang positif. Kemudian membangun komunikasi dengan orang tua murid yang difasilitasi oleh guru BK untuk meminimalisir adanya informasi yang salah mengenai perilaku seksual. Selain itu pihak sekolah juga harus berpartisipasi untuk memantau siswa (remaja) agar dapat dipastikan remaja tidak berprilaku menyimpang yang beresiko sperti pacaran tidak sehat; 6) Teman sebaya: memilih teman yang memungkinkan tidak menjerumuskan ke hal negatif.

Selain itu menurut (Wahyuni \& Fahmi, 2019) untuk meminimalisir terjadinya perilaku negatif dalam pacaran, remaja harus dibentuk dari sisi pola pikirnya, wawasan, sikap dan tanggung jawab, melalui pendidikan terlebih dahulu. Kemudian hubungan antara orang tua dengan anak juga sangat penting karena pembentukan karakter anak dapat menciptakan hubungan baik antar orang tua dan anak, yang nantinya mempermudah orang tua berkomunikasi berbagi cerita, wawasan dan terutama memberikan informasi terkait bagaimana menjaga kesehatan reproduksi. Dengan layanan informasi individu (remaja) tersebut dapat memenuhi kekurangan individu terkait informasi yang tidak diketahui. Selain orang tua teman sebaya dan lingkungan juga dapat membantu meminimalisir terjadinya dampak negatif pacaran di kalangan remaja karena terkadang teman sebaya sangat berpengaruh terhadap sikap dan perilaku remaja. teman yang soleh dapat memberikan wawasan yang benar.

Upaya yang dapat dilakukan guru BK dalam meminimalisir terjadinya dampak negatif pacaran dapat menggunakan layanan bimbingan dan konseling yaitu layanan informasi. Menurut (Hendrik \& Ratini, 2018) layanan yang tepat untuk meminimalisir dampak negatif dari perilaku negatif pacaran itu dengan layanan informasi, karena layanan informasi merupakan kegiatan yang memberikan pemahaman kepada individu untuk mencapai sesutau dengan sempurna. Dengan menggunakan layanan informasin dan metode audio visual dapat mempercepat pemahaman remaja terkait sesuatu hal yang kita informasikan. Menggunakan layanan informasi dan alat bantu seperti infokus, power point, video, dapat mempermudah pesan yang akan di sampaikan oleh guru BK terkait pemahan yang belum jelas tentang seksualitas yang terjadi pada remaja. mencegah terjadinya dampak negatif dari pacaran guru BK tentunya menggunakan layanan informasi ini agar remaja dapat memahami resiko dari perilaku pacaran, dan bagaimana menjaga kesehatan reproduksi, hingga remaja itu dapat menghindari terjadinya dampak negatif dari pacaran tersebut.

\section{KESIMPULAN}

Pacaran merupakan rasa ketertarikan antara lawan jenis yang menginikan hubungan yang lebih dari sekedar teman. Pada zaman dahulu pacaran itu sangat berhatihati dan untuk sekedar pegangan tangan saja itu hal yang tabu, namun berbeda dengan 
zaman sekarang melakukan hal lang lebih dari pegangan tangan saja sudah tak tabu lagi bagi remaja masa kini. Hal negatif ini tentu muncul karna rasa yang amat dalam menganggap bahawa seseorang yang dicintai itu harus dimilikinya, dan sepenuhnya miliknya, sampai pada remaja itu menganggap seks pranikah itu biasa. Dampak negatif dari perilaku pacaran ini disebabkan karena banyak faktor internal dan eksternal. Bahkan karena kurangnya informasi maka terjadilah rasa penasaran yang tinggi mengenai seks. Kemudian acaran dijadikan wadah bagi remaja untuk menyalurkan rasa penasarannya. Maka dari itu dengan menggunkan layanan informasi terkait pendidikan kesehatan reproduksi agar rasa penasaran itu berkurang karena sudah cukup mendapat pendidikan kesehatan reproduksi yang jelas dari layanan informasi.

\section{REFERENSI}

Evi, E., Sudirman, S., \& Suriah, S. (2013). Perilaku Seksual Pada Remaja Yang Berpacaran di SMA Negeri 2 Kairatu Kabupaten Seram Bagian Barat. MediaKesehatan Masyarakat Indonesia Universitas Hasanuddin, 9(4), 250-256.

Hastuti, S. Y. . dkk. (2017). Perilaku Pacaran Remaja Dan Faktor-Faktor Yang Mempengaruhinya Di SMAN 1 Dan SMAN 2 Kecamatan Meliau. Jurnal Mahasiswa Dan Penelitian Kesehatan. JUMANTIK, 1-14.

Hendrik, H., \& Ratini, R. (2018). Meningkatkan Pemahaman Resiko Perilaku Seksual Pra Nikah Melalui Layanan Informasi Dengan Media Audio Visual Siswa Sma Negeri 2

Mempawah.JBKI (Jurnal Bimbingan Konseling Indonesia), 3(2), 31. https://doi.org/ 10.26737/jbki.v3i2.713

Maimunah, S. (2016). Implementasi Model Kartu Eda (Ekspresi Diri Untuk Asertif) Sebagai Upaya Pencegahan Perilaku Seksual Pranikah. Seminar Nasional Dan Gelar Produk, 641-651.

Meilani, N., \& Setiyawati, N. (2017). Pengaruh Tingkat Pengetahuan dan Sikap Tentang Pacaran Terhadap Perilaku Pacaran Pada Siswa Sma di Yogyakarta. Jurnal Kesehatan Ibu Dan Anak, 11(2), 15-19. https://doi.org/10.29238/kia.v11i2.34

Rahardjo, W. (2017). Perilaku Seks Pranikah pada Mahasiswa: Menilik Peran Harga Diri, Komitmen Hubungan, dan Sikap terhadap Perilaku Seks Pranikah. Jurnal Psikologi, 44(2), 139. https://doi.org/10.22146/jpsi.23659

Wahyuni, S., \& Fahmi, I. (2019). Determinan Perilaku Seksual Pra Nikah Remaja Pria di Indonesia Hasil SDKI. Euclid, 6(2), 177. https://doi.org/10.33603/e.v6i2.2201 